\title{
The motivations, values and future plans of Australian academics
}

Emmaline Bexley, Sophie Arkoudis and Richard James

Centre for the Study of Higher Education, The University of Melbourne Level 1, 715 Swanston Street, Parkville VIC 3010, Australia

Phone: +610383448436

Fax: +610383447576

Email: bexleye@unimelb.edu.au

URL: http://www.cshe.unimelb.edu.au/

\begin{abstract}
The Australian academic profession is more differentiated than is acknowledged in national and institutional policies and academic roles are more diverse than many academics themselves may recognise. However, the evolution of the nature and purposes of the profession and its implicit diversification have been incremental and largely unplanned. A consequence of this piecemeal approach is the attitudes and pressures on academic staff uncovered by this study, including a widespread intent to leave the Australian higher education sector for other work, or work in overseas universities. The study is based on a large-scale survey of over 5,500 academics across 19 Australian universities, and explores the attitudes, motivators and career plans of the present academic workforce in Australia.
\end{abstract}

Keywords: academic workforce, work conditions, sectoral planning 
In Australian higher education, diversification of institutional missions, an aging academic workforce, cost pressures, and greater numbers of students from educationally disadvantaged backgrounds have led to a fracturing of the traditional work roles of the academic. Increased casualisation is perhaps the most obvious example of how a relatively homogenous profession has become more diverse. Yet increased casualisation is just one example of recent changes in professional practice. Other shifts at the institutional level include a growing divergence in the level of academic positions, policy drivers that reward applied over pure research, and a focus on university education as a practical preparation for the workforce. The outcome of these profound shifts in higher education has been the end of the 'traditional' norm of an academic work life comprised of scholarly research, research informed teaching, and contribution to the university through participation in management. There is no doubt that this norm has long been outmoded, yet our conceptions of the structure of academic work have not shifted to meet new realities.

This paper reports the findings of a large-scale survey of Australian academics, documenting their current work roles, attitudes and career objectives. The paper discusses the most novel and important of the project's findings, including that, on top of expected retirements, about one quarter of the academic workforce intend to move out of Australian higher education during the next ten years; an intention most frequently expressed by younger academics and strongly correlated with concerns about job security. A widespread dissatisfaction with the management and funding of higher education indicates a malaise within the profession - however this is offset, to some extent, by an almost unanimous passion for the scholarly aspects of academic work.

\section{Review of the literature and trends in the national statistics}

The Australian government collects a range of statistical data about university staff (both academic and professional). Here we discuss trends revealed in these national statistics, with reference to the broader literature on the Australian academic workforce.

\section{Casualisation of academic labour}

Perhaps the most significant change in the Australian academic workforce over the past 20 years has been the increase in the amount of teaching work undertaken by sessional staff. During the 1990s, the proportion of academic staffing with a teaching component which was sessional more than doubled, from 10 per cent of fulltime equivalent (FTE) staff load to just over 21 per cent (DEEWR selected statistics, various years). Yet these shifts in the composition of FTE staff load paint only part of the picture. Estimating the number of casual staff in Australian universities, in terms of individual people, is notoriously difficult as universities report casual staffing levels to DEEWR in FTE only, and even these are based on estimates. Junor (2004) and more recently Coates and Goedegebuure (2010) have estimated that around 40 per cent of Australian academic staff are casual employees. This compares to an average of around 25 per cent in the overall Australian workforce (Junor 2004; ABS 2009). However, new research using the superannuation records of university staff indicates that there are currently around 67,000 academics employed on a casual basis, comprising 60 per cent of the academic workforce (May 2011, forthcoming). 


\section{The demographic gap in the academic profession}

The expected increase in student participation will occur at a time when the demographic bulge of academics who entered the profession in the 1970s reaches retirement age, a problem that has been well documented (Hugo 2010, 2008, 2005abc; Skills Australia 2010; Edwards 2010; Edwards and Smith 2008 and 2010; Coates, Dobson, Edwards, Friedman, Goedegebuure and Meek, 2009; Hughes and Rubenstien, 2006). The Group of Eight (the organisation that represents Australia's eight leading research universities) estimates that a further 16,400 staff will be needed to replace those who will retire over the next 20 years, on top of those required for increased student participation. This means that in total over 40,000 extra staff is required by 2030 (Group of Eight 2010). Australia is not alone in facing the challenges posed by an ageing academic workforce. Similar patterns in the age profile of the academic workforce are evident in other nations, including Austria, Belgium, France, Germany, Iceland, Norway, Sweden, the Czech Republic and the Netherlands (OECD 2008; Huisman, de Weert and Bartelse 2002).

Changes in the age profile of the (Full Time and Fractional Full Time) Australian academic workforce are presented in Figure 1, below, which shows the shift of the 40-50 year old age group into the 50+ range over the 2000-2008 period, while the percentage contribution of the younger age groups has remained stable.

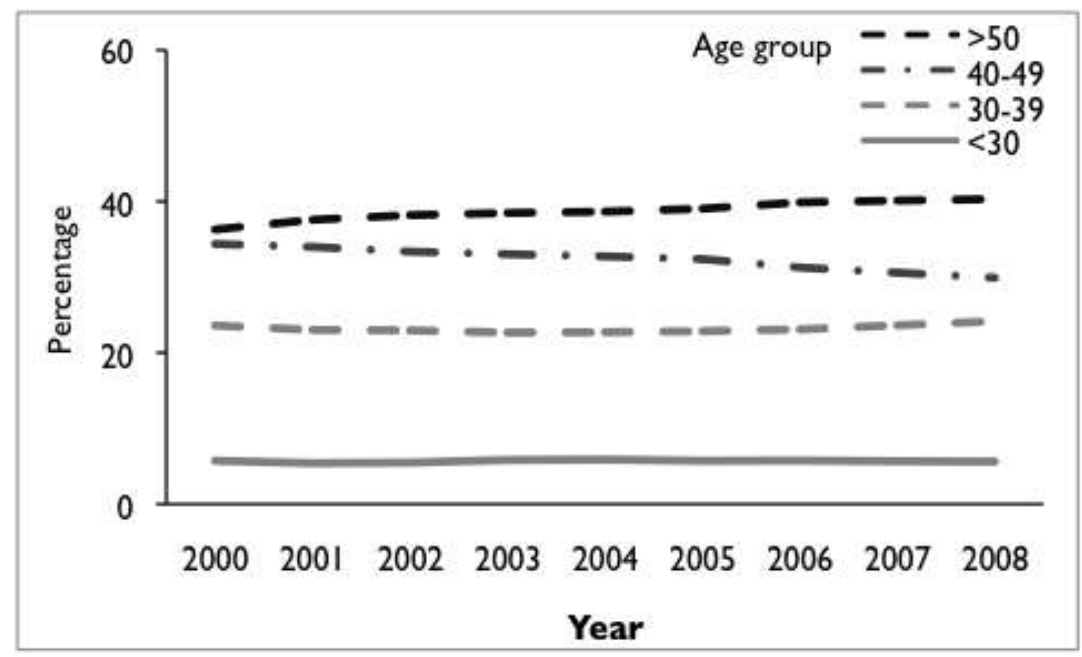

Fig. 1 Trends in age of academic staff (\%), 2000-2008. Source: DEEWR selected statistics

The concentration of older age groups in the academic workforce evident in Figure 1 has also led to imbalances in the strata of professional classifications within the sector. As older workers are more likely to hold higher level positions, the classification levels of D (Associate Professor) and E (Professor), located above Senior Lecturer or Level C, are the only classification group to have increased their percentage share within the workforce over the period from 1996; moving from having the smallest percentage share of the four classification levels, to the second highest over that period (Figure 2, below). 


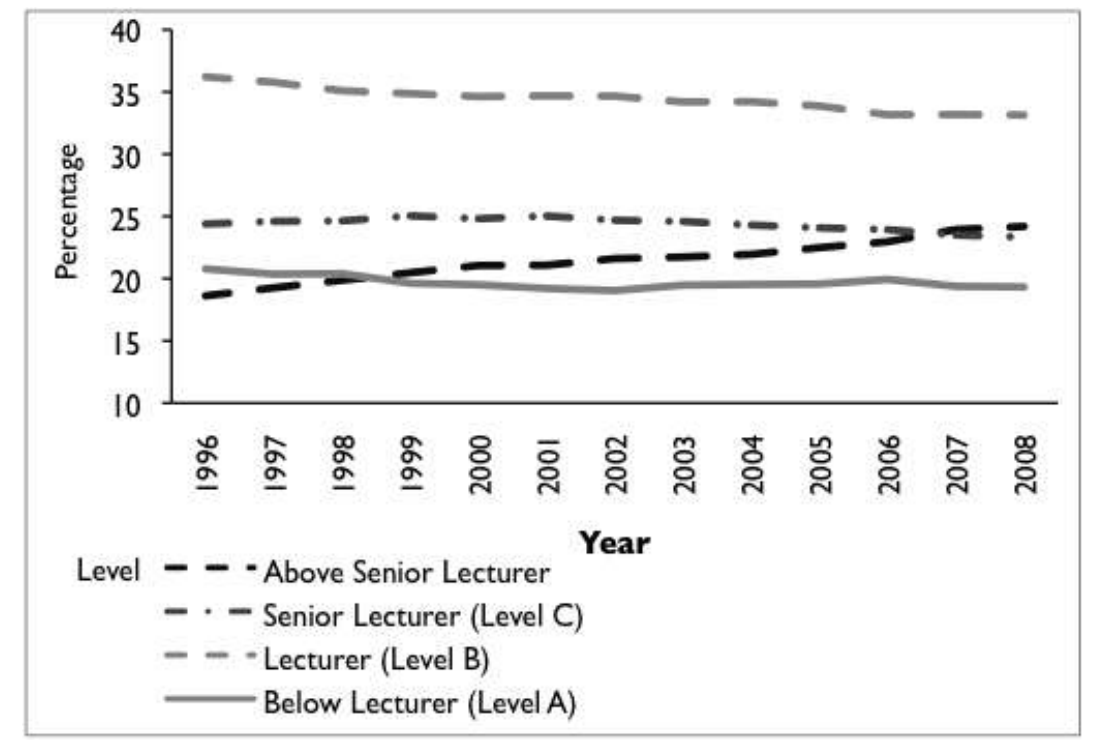

Fig. 2 Trends in proportions of academic staff by classification (\%), 1996-2008. Source: DEEWR selected statistics

These trends in employment conditions have occurred as a response to the well documented increases in student participation which have taken place since the 1970s. The Review of the National Innovation System (Cutler 2008), the Review of Higher Education (Bradley, Noonan, Nugent and Scales 2008), and the Inquiry into Research Training and Research Workforce issues in Australian Universities / Building Australia's Research Capacity undertaken by the House of Representatives Standing Committee on Industry, Science and Innovation (2008) all point toward further increases in participation in coming years, particularly by students from educationally disadvantaged backgrounds. The Group of Eight (2010) has calculated that, assuming no change in staff/student ratios and casual/non-casual ratios over the next 20 years, an additional 26,600 full-time teaching staff will be required to meet growth in participation.

\section{Studies of academic work roles}

In Australia there have been a number of survey-based research projects looking at the work roles of academics (McInnis (CSHE) 1999; Anderson, Johnson and Saha 2002; Winefield, Gillespie, Stough, Dua, Hapuarachchi \& Boyd 2003; Winefield, Boyd, Saebel, and Pignata 2008; Coates et al. 2009), as well as the present study. The Changing Academic Profession (CAP) survey, conducted in 2007 and reported in Coates et al. (2009) is perhaps the most relevant to the present study, as it is the most recent. CAP was an international study of the fulltime and fractional fulltime academic profession (it did not include casual academic staff) involving 20 countries and coordinated through a project team located at the University of Kassel. The Australian instrument was distributed across 20 Australian universities and yielded 1,370 responses at a response rate of 25 per cent (Coates, Goedegebuure, Van Der Lee, \& Meek 2008). The study found that on average Australian academics are less satisfied with their work than their international colleagues, and less satisfied with their work than other professionals in Australia. The study also found that Australian academics have a much greater propensity for employment change than their international colleagues - whether by moving professions or by moving countries. In relation to both other academics around the world, and other professionals in Australia, 
they have among the lowest levels of satisfaction with institutional management and support, have one of the lowest rates of employment on a permanent contract, and work among the longest number of hours per week.

There is a high degree of congruence between the four main studies conducted in recent years (McInnis (CSHE) 1999; Winefield et al. 2003; Anderson et al. 2002 and Coates et al. 2009). These studies paint the Australian academic workforce as heavily casualised, top-heavy in its age and classification profile, and highly mobile. The trends revealed in the national statistics confirm these characterizations. A valuable contribution of the present study is the insight it provides into how these shifts have affected the aspiration, plans, motivations and levels of satisfaction of the Australian academic workforce in 2010.

\section{The present study: background and method}

The study was based on an online survey across 20 universities that received 5,525 responses from academics, including sessional and casual staff: a response rate of approximately 16 per cent. The questionnaire sought to document academics' current work roles, attitudes and career objectives. This study builds on earlier work by the CSHE, in particular the 1999 CSHE study of academic work (McInnis 1999).

In all, 2,458 continuing staff, 1,818 limited term contract staff and 622 sessional staff responded to the survey (627 other respondents did not indicate their contract type). It is difficult to report the degree to which the sample of sessional staff is representative of the population for little is known about the characteristics, or even size, of the sessional staff population at Australian universities. This project goes some way toward addressing the paucity of information on sessional staff. The demographic characteristics of the fulltime and fractional fulltime (FT and FFT) staff in the sample showed a very close fit to that of the population of the sampled institutions as reported to DEEWR for its 2009 statistics collection, particularly in terms of level of employment, age distribution and work function (see Figure 3, below). Female respondents outweighed male respondents in the sample, as is generally the case for surveys by questionnaire.

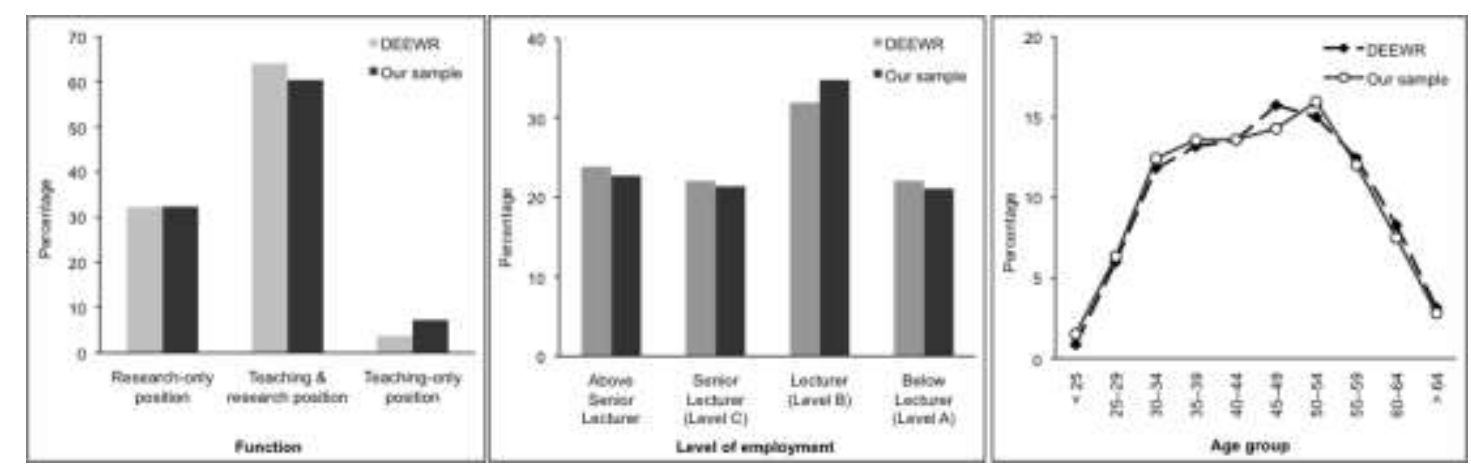

Fig. 3 Comparison of characteristics the FT\&FFT sample to corresponding population at participating institutions in DEEWR 2008

Findings are reported as proportions with 95 per cent confidence intervals following the method for proportions developed by Newcomb and Altman (2000). The 95 per cent confidence intervals acknowledge the 
chance (at 5\%) that the population value is not contained in the interval. Statistical significance can be read directly from the 95 per cent confidence intervals such that when 95 per cent confidence intervals (on independent group data) overlap by less than one quarter of the average of their total widths, the difference between the two estimates is statistically significant at $\mathrm{p}<0.05$ (Cumming and Finch 2005).

\section{Findings}

\section{Attractors to academic work}

The findings show that of the possible factors attracting people to academic work, those most valued centre almost solely on scholarly, intellectual activities. The opportunity for intellectually stimulating work (95.9 per cent), passion for a field of study (93.8 per cent) and the opportunity to contribute to new knowledge (91.1 per cent) are the aspects of academic work most likely to have drawn academics to the sector.

Table1: Proportion agreeing or strongly agreeing that the aspect of work indicated drew them to the profession. 95\% CIs

\begin{tabular}{|c|c|c|c|}
\hline & Percentage & $\mathbf{n}$ & $95 \% \mathrm{CI}$ \\
\hline Opportunities for intellectually stimulating work & 95.9 & 5270 of 5495 & 95.3 to 96.4 \\
\hline Genuine passion for a field of study & 93.8 & 5154 of 5496 & 93.1 to 94.4 \\
\hline Opportunity to contribute to new knowledge & 91.1 & 4990 of 5478 & 90.3 to 91.8 \\
\hline Autonomy and control over working life & 85.8 & 4714 of 5495 & 84.8 to 86.7 \\
\hline Opportunities to research, write and publish & 81.3 & 4461 of 5490 & 80.2 to 82.3 \\
\hline Chance to work in a collegial environment & 72.7 & 3978 of 5473 & 71.5 to 73.8 \\
\hline Passion for teaching & 65.1 & 3568 of 5479 & 63.8 to 66.4 \\
\hline Opportunities to supervise research students & 59.3 & 3239 of 5463 & 58.0 to 60.6 \\
\hline Chance to do basic, blue sky research & 58.9 & 3207 of 5448 & 57.6 to 60.2 \\
\hline Opportunities for community engagement & 58.3 & 3194 of 5476 & 57.0 to 59.6 \\
\hline Good or satisfactory income & 57.5 & 3150 of 5481 & 56.2 to 58.8 \\
\hline Job security & 57.2 & 3128 of 5467 & 55.9 to 58.5 \\
\hline Opportunities to travel & 48.9 & 2675 of 5473 & 47.6 to 50.2 \\
\hline Status of the profession in the public eye & 33.7 & 1845 of 5473 & 32.5 to 35.0 \\
\hline
\end{tabular}

Academics' commitment to the scholarly aspects of their work was also apparent in the qualitative aspects of the survey. Academics were asked to provide written responses to the statement, "The most satisfying aspect of my academic work or career is...?" Of the over 4200 comments provided, most were focused on the pleasure of teaching and seeing students and research candidates experience moments of clarity and understanding in their learning, and on making breakthroughs in research problems. Interaction with a community of scholars and achieving highly in their field were also common responses. A selection of comments which typify the written responses to this question were: 
"The best moments of teaching, when I feel like it is an aspect of my teaching that has made the difference for a student and the best moments of scholarly writing, when you feel like you have made a breakthrough..."

"Creating new researchers with high level skills and confidence and discovering new knowledge through PhD supervision."

"Autonomy and the thrill of novel research findings."

\section{Experiences of teaching}

Academics with a teaching role were often concerned about a perceived lack of basic academic skills among students, and expressed concern that this problem was becoming worse. Only half believed that good teaching was valued at their institutions.

Table 2: Proportion of respondents and agreeing and disagreeing with specified statements. 95\% CIs.

\begin{tabular}{|c|c|c|c|c|}
\hline & $\begin{array}{c}\text { Disagree } \\
\text { (percentage) }\end{array}$ & $\begin{array}{c}95 \% \\
\text { CI }\end{array}$ & $\begin{array}{c}\text { Agree } \\
\text { (percentage) }\end{array}$ & $\begin{array}{c}95 \% \\
\text { CI }\end{array}$ \\
\hline $\begin{array}{l}\text { The changing expectations of students are } \\
\text { a concern for me }(n=4579)\end{array}$ & 14.0 & $\begin{array}{c}13.0 \\
\text { to } \\
15.0\end{array}$ & 67.2 & $\begin{array}{c}65.8 \\
\text { to } \\
68.5\end{array}$ \\
\hline $\begin{array}{l}\text { I spend more time than I would like } \\
\text { teaching basic skills due to students } \\
\text { deficiencies }(n=4250)\end{array}$ & 18.8 & $\begin{array}{l}17.7 \\
\text { to } \\
20.0\end{array}$ & 60.4 & $\begin{array}{c}58.9 \\
\text { to } \\
61.8\end{array}$ \\
\hline $\begin{array}{l}\text { Good teaching is valued in my university } \\
(n=4666)\end{array}$ & 24.6 & $\begin{array}{l}23.4 \\
\text { to } \\
25.8\end{array}$ & 54.2 & $\begin{array}{l}52.8 \\
\text { to } \\
55.6\end{array}$ \\
\hline
\end{tabular}

\section{Experiences of the research environment}

Academics with a research role were most likely to be concerned about the paucity of available research funding, and a lack of time to undertake, and write up, their research.

Table 3: Proportion of respondents and agreeing and disagreeing with specified statements. 95\% CIs.

\begin{tabular}{|c|c|c|c|c|}
\hline & $\begin{array}{c}\text { Disagree } \\
\text { (percentage) }\end{array}$ & $\begin{array}{c}95 \% \\
\text { CI }\end{array}$ & $\begin{array}{c}\text { Agree } \\
\text { (percentage) }\end{array}$ & $\begin{array}{c}95 \% \\
\text { CI }\end{array}$ \\
\hline $\begin{array}{l}\text { I have freedom to pursue my own } \\
\text { research interests }(n=4772)\end{array}$ & 19.5 & $\begin{array}{c}18.4 \\
\text { to } \\
20.7\end{array}$ & 61.5 & $\begin{array}{c}60.1 \\
\text { to } \\
62.9 \\
\end{array}$ \\
\hline $\begin{array}{l}\text { I'm confident I can publish in good } \\
\text { journals }(n=4739)\end{array}$ & 21.4 & $\begin{array}{c}20.3 \\
\text { to } \\
22.6\end{array}$ & 59.0 & $\begin{array}{c}57.6 \\
\text { to } \\
60.4\end{array}$ \\
\hline $\begin{array}{l}\text { I have adequate opportunities to do } \\
\text { basic, blue-sky research }(n=4369)\end{array}$ & 42.5 & $\begin{array}{c}41.0 \\
\text { to } \\
43.9\end{array}$ & 30.3 & $\begin{array}{c}29.0 \\
\text { to } \\
31.7\end{array}$ \\
\hline $\begin{array}{l}\text { I'm confident I can get research grants } \\
(n=4637)\end{array}$ & 49.1 & $\begin{array}{c}47.6 \\
\text { to } \\
50.5\end{array}$ & 28.4 & $\begin{array}{c}27.1 \\
\text { to } \\
29.7\end{array}$ \\
\hline $\begin{array}{l}\text { I have enough time for research } \\
(n=4783)\end{array}$ & 62.1 & $\begin{array}{c}60.7 \\
\text { to } \\
63.4\end{array}$ & 22.1 & $\begin{array}{c}21.0 \\
\text { to } \\
23.3\end{array}$ \\
\hline There is sufficient time available for my & 60.5 & 59.1 & 20.3 & 19.2 \\
\hline
\end{tabular}




\begin{tabular}{|c|c|c|c|c|}
\hline scholarly writing $(n=4680)$ & & $\begin{array}{c}\text { to } \\
61.9\end{array}$ & & $\begin{array}{c}\text { to } \\
21.5\end{array}$ \\
\hline $\begin{array}{l}\text { Levels of grant funding are adequate } \\
(\mathrm{n}=4531)\end{array}$ & 65.5 & $\begin{array}{c}64.1 \\
\text { to } \\
66.9 \\
\end{array}$ & 12.4 & $\begin{array}{c}11.5 \\
\text { to } \\
13.4\end{array}$ \\
\hline
\end{tabular}

\section{The general experience of academic work}

While the findings around teaching and research, above, did not vary greatly between career stage, on other matters there was a high degree of variation between the experiences of early, mid and late career academics. Around half of mid and late career academics reported: an unmanageable workload; a poor work/life balance; having to undertake an unreasonable amount of administrative work; and suffering considerable job related stress. Early career academics' concerns where with job security and level of income. Interestingly, the later the career-stage of the participant, the more likely they were to believe it was not a good time for a young person to aspire to an academic career.

Table 4: Proportion of respondents and agreeing and disagreeing with specified statements. 95\% CIs.

\begin{tabular}{|c|c|c|c|c|}
\hline Career stage & $\begin{array}{c}\text { Disagree } \\
\text { (percentage) }\end{array}$ & $95 \% \mathrm{CI}$ & $\begin{array}{c}\text { Agree } \\
\text { (percentage) }\end{array}$ & $95 \% \mathrm{CI}$ \\
\hline \multicolumn{5}{|c|}{ My overall workload is reasonable and manageable $(\mathrm{n}=5017)$} \\
\hline Early & 36.9 & 34.6 to 39.1 & 39.5 & 37.3 to 41.8 \\
\hline Mid & 57.3 & 55.1 to 59.5 & 24.5 & 22.6 to 26.5 \\
\hline Late & 56.1 & 52.7 to 59.5 & 27.8 & 24.8 to 30.9 \\
\hline TOTAL & 48.0 & 46.6 to 49.3 & 31.7 & 30.4 to 33.0 \\
\hline \multicolumn{5}{|c|}{ Overall, I have a good work/life balance $(\mathrm{n}=5018)$} \\
\hline Early & 34.7 & 32.5 to 37.0 & 44.7 & 42.4 to 47.0 \\
\hline Mid & 49.8 & 47.6 to 52.0 & 27.2 & 25.3 to 29.2 \\
\hline Late & 48.7 & 45.4 to 52.1 & 30.2 & 27.2 to 33.4 \\
\hline TOTAL & 42.8 & 41.4 to 44.1 & 35.2 & 33.9 to 36.5 \\
\hline \multicolumn{5}{|c|}{ I undertaken an unreasonable amount of administrative work $(\mathrm{n}=4735)$} \\
\hline Early & 36.9 & 34.6 to 39.2 & 37.1 & 34.8 to 39.5 \\
\hline Mid & 24.6 & 22.7 to 26.6 & 53.4 & 51.1 to 55.6 \\
\hline Late & 25.3 & 22.4 to 28.5 & 53.2 & 49.7 to 56.6 \\
\hline TOTAL & 29.9 & 28.6 to 31.2 & 46.5 & 45.1 to 48.0 \\
\hline \multicolumn{5}{|c|}{ I have good job security $(\mathrm{n}=4867)$} \\
\hline Early & 57.9 & 55.6 to 60.2 & 25.7 & 23.7 to 27.8 \\
\hline Mid & 36.1 & 34.0 to 38.3 & 47.4 & 45.2 to 49.7 \\
\hline Late & 23.6 & 20.8 to 26.7 & 61.1 & 57.6 to 64.4 \\
\hline TOTAL & 42.9 & 41.5 to 44.3 & 40.5 & 39.1 to 41.9 \\
\hline \multicolumn{5}{|c|}{ My job is a source of considerable personal stress $(\mathrm{n}=4919)$} \\
\hline Early & 38.2 & 35.9 to 40.5 & 38.2 & 36.0 to 40.6 \\
\hline Mid & 26.9 & 25.0 to 28.9 & 49.5 & 47.3 to 51.7 \\
\hline Late & 27.9 & 25.0 to 31.1 & 47.8 & 44.4 to 51.2 \\
\hline TOTAL & 31.5 & 30.2 to 32.8 & 44.6 & 43.2 to 46.0 \\
\hline \multicolumn{5}{|c|}{ I am satisfied with my level of income $(\mathrm{n}=4924)$} \\
\hline Early & 40.6 & 38.3 to 42.9 & 34.6 & 32.5 to 36.9 \\
\hline Mid & 34.8 & 32.7 to 36.9 & 40.4 & 38.3 to 42.7 \\
\hline Late & 28.4 & 25.4 to 31.6 & 51.2 & 47.8 to 54.6 \\
\hline TOTAL & 35.9 & 34.6 to 37.3 & 39.9 & 38.6 to 41.3 \\
\hline
\end{tabular}

This is not a good time for any young person to aspire to an academic career in my discipline $(n=4826)$ 


\begin{tabular}{r|ll|ll} 
Early & 40.0 & 37.7 to 42.3 & 38.9 & 36.6 to 41.2 \\
Mid & 29.6 & 27.5 to 31.7 & 49.5 & 47.2 to 51.7 \\
Late & 27.7 & 24.7 to 30.9 & 56.3 & 52.9 to 59.7 \\
TOTAL & 33.3 & 32.0 to 34.7 & 46.4 & 44.9 to 47.8 \\
\hline
\end{tabular}

\section{Short-term and long-term career plans}

Nearly three-quarters of academics (73.5 per cent) indicated an intent to continue in their current role and position in the short term. However, substantial proportions of academics indicated longer term intentions (for the next five to ten years) to move to another higher education institution ( 28.9 per cent); to move to an overseas institution (24.6 per cent); to leave the higher education sector all together (25.9 per cent); or to retire (20.5 per cent). On top of expected retirements, over one quarter of the academic workforce appears to have serious intentions to move out of Australian higher education during the next ten years (Table 5, below).

Table 5: Proportion of respondents and agreeing and disagreeing with specified statements. 95\% CIs.

\begin{tabular}{|c|c|c|c|c|c|c|}
\hline & \multicolumn{3}{|c|}{ Short term plans } & \multicolumn{3}{|c|}{ Long term plans } \\
\hline & $\begin{array}{l}\text { Percentage } \\
\text { (of 4814) }\end{array}$ & $\mathbf{n}$ & $\begin{array}{c}95 \% \\
\text { CI }\end{array}$ & $\begin{array}{l}\text { Percentage } \\
\text { (of 4814) }\end{array}$ & $\mathbf{n}$ & $\begin{array}{c}95 \% \\
\text { CI }\end{array}$ \\
\hline Retire & 4.3 & 205 & $\begin{array}{c}3.7 \text { to } \\
4.9 \\
\end{array}$ & 20.5 & 988 & $\begin{array}{c}19.4 \text { to } \\
21.7\end{array}$ \\
\hline $\begin{array}{l}\text { Management position in own or } \\
\text { other higher education/research } \\
\text { institution }\end{array}$ & 4.5 & 218 & $\begin{array}{l}4.0 \text { to } \\
5.2\end{array}$ & 11.6 & 560 & $\begin{array}{l}10.8 \text { to } \\
12.6\end{array}$ \\
\hline $\begin{array}{l}\text { An academic position in another } \\
\text { country }\end{array}$ & 6.9 & 333 & $\begin{array}{c}6.2 \text { to } \\
7.7\end{array}$ & 24.6 & 1184 & $\begin{array}{c}23.4 \text { to } \\
25.8\end{array}$ \\
\hline $\begin{array}{l}\text { Work outside higher } \\
\text { education/research institutes }\end{array}$ & 10.0 & 483 & $\begin{array}{c}9.2 \text { to } \\
10.9 \\
\end{array}$ & 25.9 & 1248 & $\begin{array}{c}24.7 \text { to } \\
27.2\end{array}$ \\
\hline $\begin{array}{l}\text { An academic position in another } \\
\text { higher education/research institute } \\
\text { within Australia }\end{array}$ & 11.8 & 567 & $\begin{array}{l}10.9 \text { to } \\
12.7\end{array}$ & 28.9 & 1390 & $\begin{array}{l}27.6 \text { to } \\
30.2\end{array}$ \\
\hline $\begin{array}{l}\text { Seek promotion within current } \\
\text { institution }\end{array}$ & 33.2 & 1599 & $\begin{array}{c}31.9 \text { to } \\
34.6\end{array}$ & 34.0 & 1639 & $\begin{array}{c}32.7 \text { to } \\
35.4\end{array}$ \\
\hline $\begin{array}{l}\text { Continue in current role and } \\
\text { position }\end{array}$ & 73.6 & 3542 & $\begin{array}{l}72.3 \text { to } \\
74.8\end{array}$ & 14.7 & 717 & $\begin{array}{c}13.7 \text { to } \\
15.7\end{array}$ \\
\hline
\end{tabular}

A number of cross-analyses were undertaken to better understand the characteristics of those intending to depart the Australian higher education sector. By far the strongest factor associated with the intention to move to an overseas institution, or to leave higher education all together, was age. Younger academics are far more likely than older academics to be planning to move out of work in Australian universities. These findings were both large and statistically significant. Figure 4, below, shows that close to 40 per cent of academics under 30 plan to leave Australian higher education in the next five to ten years, with 13 to 18 per cent indicating an intention to leave in the immediate future. Around one third of staff aged 30-39 intend to leave in the next five to ten years; 8 to 11 per cent in the short term. 


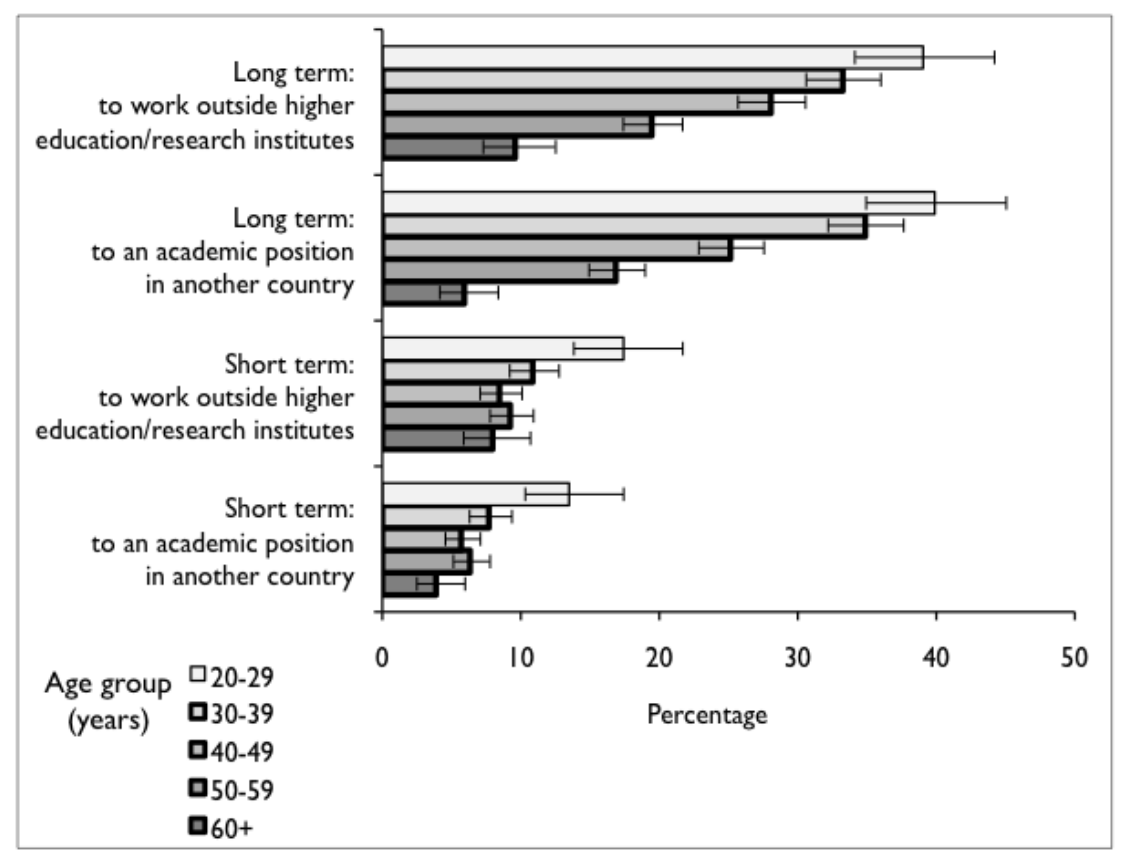

Fig. 4 Long and short-term career plans of academics, by age group (error bars are 95\% CIs)

The study investigated differences between those intending to leave and those intending to stay in relation to levels of satisfaction and other opinions. The main difference between the two groups ('leavers' and 'stayers') that stood out above all others was a greater likelihood of dissatisfaction with income and with job security: 49.9 per cent of 'leavers' indicated that they do not have good job security, compared with 39.7 per cent of other academics; and 42.4 per cent indicated that they are not satisfied with their level of income, compared with 33.6 per cent of academics who are not planning to move overseas (see Figure 5 below).

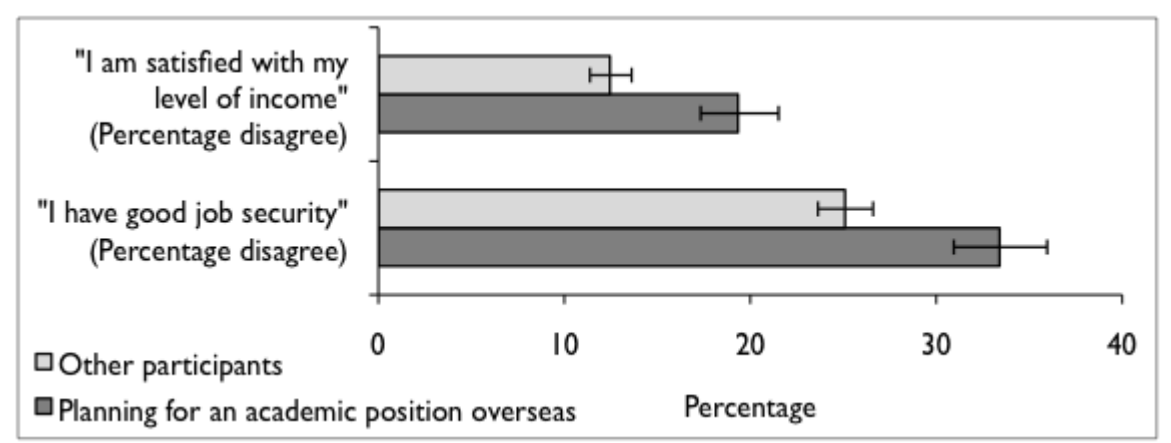

Fig. 5 Proportion of academics planning to move to an overseas university who strongly disagreed with the propositions, "I am satisfied with my level of income," and "I have good job security." Error bars are 95\% CIs 


\section{Who are Australia's sessional academics?}

An important contribution of the study was shedding more light on Australia's sessional academic workforce. This group has been under-studied in the past, as was suggested earlier in the account of the previous research. Exact figures on the numbers of sessional (or casual) academics employed by universities are not kept by DEEWR, and definitive population characteristics of sessional and casual academics are therefore unavailable. The demographic characteristics for survey participants who work in a sessional or casual capacity, tabulated below, are therefore both valuable and somewhat problematic. They provide a rare snapshot of the sessional academic workforce, though we do not have reliable population-level data against which to benchmark the findings. ${ }^{1}$

Almost two-thirds of the sessional academics surveyed were female, and just over two-thirds were born in Australia. While most were at Level A (64.6 per cent) many were at more senior levels. Almost two-thirds (63.9 percent) were in teaching only positions. There was a large spread of age groups, with more than half over the age of 40. Only 48.9 per cent were currently studying: far less than fits the often prevalent assumption that most sessional academics are doctoral students. More than a quarter had been in their position for over five years.

Table 8: Characteristics of surveyed sessional academics. 95\% CIs. $\mathrm{N}=622$.

\begin{tabular}{lrc|c}
\hline & & Percentage & 95\% CI \\
\hline Sex & Female & 63.7 & 59.7 to 67.5 \\
ATSI & Male & 36.3 & 32.5 to 40.3 \\
\hline Place born & Yes & 1.3 & 0.7 to 2.6 \\
\hline Age group & Australia & 67.0 & 63.2 to 70.6 \\
& Overseas & 33.0 & 29.4 to 36.8 \\
\hline Highest & $20-29$ & 22.2 & 19.1 to 25.7 \\
qualification & $30-39$ & 20.9 & 17.8 to 24.3 \\
& $40-49$ & 24.7 & 21.5 to 28.4 \\
& $50-59$ & 20.9 & 17.8 to 24.3 \\
& $60+$ & 11.2 & 8.9 to 14.0 \\
\hline Currently & Bachelor & 23.5 & 20.2 to 27.0 \\
studying & Masters & 35.5 & 31.8 to 39.4 \\
\hline Course & Other postgraduate & 18.1 & 15.2 to 21.4 \\
& PhD & 22.9 & 19.8 to 26.5 \\
\hline Position & No & 51.1 & 47.1 to 55.1 \\
& Yes & 48.9 & 44.9 to 52.9 \\
\hline & Bachelor & $3.5^{*}$ & 1.9 to 6.4 \\
& Teaching and research & 26.4 & 23.0 to 30.2 \\
& Research only & 7.1 & 5.3 to 9.5 \\
& & $13.5^{*}$ & 10.0 to 18.0 \\
& Other postgraduate & $10.6 *$ & 7.6 to 14.8 \\
& PhD & $72.3 *$ & 66.8 to 77.2 \\
\hline & 63.9 & 59.9 to 67.7 \\
& & &
\end{tabular}

\footnotetext{
${ }^{1}$ Confidence intervals, and similarly evaluations of statistical significance, presuppose a random sample with a normal distribution. Due to the difficulties in administering the survey to sessional staff, outlined above, we cannot be confident that the sessional sample is truly random. These data should be treated as indicative only and interpreted with caution.
} 


\begin{tabular}{rrc|c} 
& Postdoctoral & 2.1 & 1.2 to 3.6 \\
\hline Years in position & $<1$ year & 13.6 & 11.0 to 16.8 \\
1 year - 23 months & 24.2 & 20.8 to 28.0 \\
2 years - 35 months & 15.3 & 12.5 to 18.6 \\
3 years - 47 months & 13.6 & 11.0 to 16.8 \\
4 years - 59 months & 6.5 & 4.7 to 8.9 \\
$5-9$ years & 17.1 & 14.2 to 20.5 \\
& $10+$ years & 9.7 & 7.5 to 12.5 \\
\hline Level & Level A & 64.6 & 59.9 to 69.0 \\
& Level B & 27.2 & 23.2 to 31.7 \\
Level C & 4.1 & 2.6 to 6.5 \\
& D and above & 4.1 & 2.6 to 6.5 \\
\hline
\end{tabular}

* Note: Proportions for qualification currently studying is of the group studying only. $\mathrm{N}=282$.

The most common forms of work undertaken by sessional academics were tutoring $(79.9 \%$; $95 \% \mathrm{CI}=76.6$ to 82.9) and lecturing $(55.0 \%$; $95 \% \mathrm{CI}=51.1$ to 58.9$)$, and a substantial proportion also have a teaching coordination role $(19.1 \% ; 95 \% \mathrm{CI}=16.2$ to 22.4$)$.

The primary theme repeated throughout the open comment sections by sessional academics was the desire for more secure employment conditions. These claims are supported by the nature of participants' employment arrangements, with 64.0 per cent indicating that their sessional work was comprised of a reasonably regular series of short term contracts. The study did not indicate why these effectively 'continuing' academics are not offered more stable, long-term contracts. Only 18 per cent reported their work to be irregular or sporadic oneoff contracts, while another 18 per cent reported their work being on an occasional hourly basis. A typical comment about sessional work conditions was:

\begin{abstract}
"I received three commendations for excellence in teaching in my time, but there were no opportunities for me to move beyond casual work. I was lurching from contract to contract and filling out time sheets. I had better working conditions at my first job at Hungry Jacks."
\end{abstract}

When asked why they are working in a sessional capacity, many indicated that they work in a sessional capacity because no ongoing academic positions are available to them $(21.3 \%$; $95 \% \mathrm{CI}=18.2$ to 24.7$)$, or to prepare for an academic career $(18 \% ; 95 \% \mathrm{CI}=15.2$ to 21.2$)$. One in five $(20.1 \%$; $95 \% \mathrm{CI}=17.1$ to 23.5$)$ said that they use sessional work as a source of income while studying. Again, these findings contradict many prevalent assumptions about sessional academics being young HDR students supplementing scholarship income (the career plans of Higher Degree Research candidates are explored in Edwards, Bexley, and Richardson (2010).

\title{
Academics' thoughts on replenishing, developing and maintaining the workforce
}

Respondents were asked to offer their views regarding how universities could replenish, develop and maintain the academic workforce. About a third of responses referred to the obvious solution of increasing funding to universities in order to employ more academic staff, decrease workloads, increase salaries and offer better job 
security. Around five per cent of the respondents indicated that the matter is too complex and difficult to address. The remaining comments focussed on issues concerning institutional recognition and support for the diverse work roles and career development needs of academic staff.

Many of the academics' comments clearly reflected the diversity of academic work roles and responsibilities, and also the lopsidedness and overload that often comes with these complex work portfolios. Comments such as "we can't all be expected to do everything" reveal the frustration that many academics feel about aligning their academic roles within a one-size-fits-all model of academic work. It was clear that very few academics believed that they could adequately balance the teaching/research/administration roles to the level that seems to be expected within their universities. Typical comments included:

\begin{abstract}
"Even though there is a spoken acknowledgement that all three (teaching, research, and service) are important, every academic knows there is a hierarchy, with research sitting at the top... I think academic institutions forget that we need a blended balance of strong teachers and strong researchers in order to make the university viable and profitable--and we can't expect that we'll get both out of one person who has any sort of work-life balance!"
\end{abstract}

By far the strongest critical comments were reserved for management of universities. Academics indicated that over-managerialism in universities has resulted in low morale within the academic workforce. There is a perception that universities have lost sight of the main game - with many academics expressing their frustration that increased time spent on administrative tasks driven by the accountability and auditing purposes of management, means that they have less time available for their academic work. Typical comments include:

"Much of what I value most about academic work--that is, working with ideas, generating new knowledge, and pursuing lines of inquiry for which my scholarly background best equips me--is continually undermined by the techno-bureaucratic nonsense of 'quality' audits and the farcical pretence that perpetual competition, ranking and measuring somehow produces improvements."

"Management systems need to be restructured - management needs to conceive of itself as serving the academic community, not monitoring it."

In order to redress this, many academics suggested that universities could restructure work practices, so that professional staff can undertake more administrative duties, where appropriate, allowing more time for academics to focus on their academic work. This could be interpreted as a call to shift professional staff load from the top of the classification scale, to more mid-level support.

\title{
Discussion
}

This study reveals significant challenges for the organisation and management of the Australian academic workforce. Three issues stand out. First, anticipated retirements, career changes and possible overseas departures suggest a major shortfall in supply may be imminent if sufficient new staff are not employed. Second, an extended period of casualisation of academic employment (in research, short and medium term 
contracts prevail; in teaching, sessional work is the norm) has created a gap in the development provided for younger, and to some extent mid-career, academics. Third, many academics in mainstream teaching and research positions are overwhelmed by their workloads and the range of their responsibilities, and are concerned that the opportunities for creativity, innovation and originality are being eroded. These three issues have significant implications for the continued quality and relevance of teaching and research in Australian higher education.

It is likely that the performance capacity of the academic profession, as it is presently structured, is nearing (or has reached) its limits. A systematic response is therefore needed to the unmanaged growth in the expectations on academic staff - in terms of rising students numbers, increased administrative- and accountability-related work, and increasing pressure to produce measurable outputs (publications, grants, etc) - and the accompanying unplanned diversification of academic work roles. Such a response should explicitly acknowledge that a transitional stage has been reached in the creation of a more heterogeneous profession, and establish the processes for building new recruitment, appointment and promotion policies.

There is an evident tension running through the findings and commentary we report here: there is an urgent need to recognise and legitimise the ubiquity of 'non-traditional' modes of academic work, yet much of the dissatisfaction with these new modes of work stems from the absence of traits closely aligned to traditional roles. To some extent, this is because the way academic work is valued is based on outmoded notions. However, there are deeper issues at play. Consider the characteristics of traditional, tenured positions: autonomy; a balance of research, teaching and service; job security (perhaps a job for life), and clear and largely linear career pathways. New modes of academic work are often less autonomous (subjects taught are more likely to be offered due to student demand or business plans than the interests of the course coordinator, and research tends to follow funding); they are likely to be exclusively based in teaching or research, and to contain little scope for service. They are certainly not jobs for life, are unlikely to follow clear career pathways, and may be comprised of punctuated periods in different work roles and even different institutions. Addressing the levels of dissatisfaction experienced by academics in non-traditional roles requires more than denormalising the idea of 'traditional' academic work or simply giving more legitimacy to other forms of work (although this is important). Some of the non-traditional modes of work are at best unfair and at worst exploitative. At the same time, it ought to be possible to design jobs that fit more heterogeneous roles and work profiles, more diverse sources of funding, and more complex social demands, and yet that are intellectually satisfying, self-managed and creative.

Most importantly, new modes of academic work should still provide ongoing job security (even if not a job for life); while for their part, academic staff should be able to envisage and navigate satisfying career pathways even if these are non-linear. The contemporary Australian university environment has evolved to make service to society, rather than simply the accumulation of knowledge, its primary function. Traditional conceptions of academic work cannot be the norm in this environment. But this does not mean the higher education system should abandon those aspects of traditional modes of work that retain an enduring value. 


\section{Conclusion}

In a higher educational sector characterised by increasing levels of institutional diversity, institutional responses to the present situation can be expected to differ considerably, and policy at the national level needs to allow for institutional differences: a uniform approach is undesirable and unlikely. While it is beyond the scope of the present paper to prescribe a remedy to the pressures described above, we offer a number of principles that might underlie responses by institutions and by government.

Firstly, a more sophisticated distribution of academic work roles is needed. The present norms of teaching and research positions (often tenured), teaching-only positions (often sessional) and research only positions (often fixed term), are overly rigid, and do not provide adequate scope for career development for teaching-specialist and research-specialist staff. In particular, appropriate career pathways and promotion opportunities for teaching-specialist academic work should be ubiquitous across the sector. Ensuring that excellence in teaching is defined and recognised as a viable path to progressing through a successful career will be an essential element in achieving an effective differentiation of academic work roles.

That said, the primacy of the research-teaching nexus in the work of universities should be maintained, for it is integral to maintaining the quality and meaning of higher education. In practical terms, the present settings often throw research and teaching into direct competition for academics' time: productivity and effectiveness in one area is achieved at the expense of the other, at least in part. A less simplistic consideration of the nexus, which focuses on the interplay between teaching and research at the department level, rather than in the work of the individual academic, is a practical approach in the present, mass higher education setting.

While a certain level of casualisation is both necessary and desirable for efficiencies and effectiveness (including for providing opportunities for HDR candidates and adjunct staff), the prevalence of casual and short-term contracts has undermined the sustainability of the academic profession. To ensure that projected growth in student participation, and the retirement of older staff, do not result in staff shortages, institutions should explore strategies for shifting casual and short-term staff load to long-term and ongoing contracts. As the main impediment to the provision of more secure positions appears to be uncertainty around finance and planning at the work-unit level, institutional employment policies might ensure that a greater proportion of this cost/risk is carried at the institution level. Further, a better understanding of the volume and character of the work undertaken by casual/sessional and short-term contract academics is needed. Data of this kind might be collected through DEEWR's statistical reporting processes, while acknowledging the additional administrative burden this would create for institutions - a burden which is itself a growing problem.

Reducing this administrative burden requires ongoing and over-arching monitoring of accountability and auditing processes by government, and a structured approach to business process reform of reporting by institutions. At the institutional level, there is a need for the development of a new and specialised kind of professional staff. At present, academic staff undertake many tasks that are in essence administrative, and peripheral to core academic duties around teaching and research, such as reporting activities for audits and performance measurements (of publications, grant histories, etc); preparation of grant applications; and subject coordination tasks (such as data entry for grading and other administration). Such tasks often require expertise 
in academic management, but need not be undertaken by academics themselves. These duties might better be undertaken by a new kind of specialist professional staff, freeing academic staff to focus on their own core duties.

Finally, institutions should be cautious about replicating national funding formulae at the academic unit level. Internal funding allocation to academic units often mirrors allocative mechanisms at the national level, for this is a rational institutional strategy. Monitoring the effect of national funding allocation formulae on unit-level staffing decisions needs to become a greater priority in the assessment and development of national policy. 


\section{References}

Anderson, D., Johnson, R., and Saha, L. (2002). Changes in Academic Work: Implications for Universities of the Changing Age Distribution and Work Roles of Academic Staff. Canberra: Commonwealth of Australia.

Anibas, M., Hanson-Brenner, G., and Zorn, C. (2009). Experiences described by novice teaching academic staff in baccalaureate nursing education: a focus on mentoring. Journal of Professional Nursing, 25 (4), 211-127.

Australian Bureau of Statistics (ABS) (2008). Forms of employment. Yearbook Australia. Cat. 1301.0

Australian Bureau of Statistics (ABS) (2009). Casual employees. Cat. 4102.0

Bradley, D., Noonan, P., Nugent, H., and Scales, B. (2008). Review of Higher Education in Australia, Final Report. Canberra: Australian Government.

Coates, H., Goedegebuure, L., Van Der Lee, J., \& Meek, L. (2008). The Australian academic profession: a first overview. In RIHE International Seminar Reports: No. 12. The changing academic profession in international comparative and quantitative perspectives: report of the International Conference on the Changing Academic Profession Project, 2008. Hiroshima, Japan: Research Institute for Higher Education, Hiroshima University, 179-202.

Coates, H., Dobson, I., Edwards, D., Friedman, T., Goedegebuure, L., and Meek, L. (2009). Changing academic profession: The attractiveness of the Australian academic profession: A comparative analysis. Research briefing. Melbourne: Australian Council for Educational Research, LH Martin Institute for Higher Education Leadership and Management, Educational Policy Institute.

Coates, H., Goedegebuure, L. (2010). The Real Academic Revolution: Why we Need to Reconceptualise Australia's Future Academic Workforce, and Eight Possible Strategies for How to Go About This. Research Briefing, LH Martin Institute.

Cumming, G., and Finch, S. (2005). Inference by eye: Confidence intervals, and how to read pictures of data. American Psychologist, 60, 170-180.

Cutler, T. (2008). Venturous Australia: Building Strength in Innovation. Melbourne: Cutler and Company.

Dawson, N. (2007). Post postdoc: are new scientists prepared for the real world?, Bioscience, 57(1), 16.

DEEWR (2009). Staff 2009: Selected Higher Education Statistics. Number of Full-time and Fractional Fulltime Staff by Current Duties Term, 1996 to 2009. 
DEEWR (2009a). Staff 2008: Selected Higher Education Statistics, Appendix 1.5. FTE for Actual Casual Staff by State, Higher Education Provider and Current Duties Classification, 2007.

DEEWR (2009b). Staff 2008: Selected Higher Education Statistics. Appendix 1.12. FTE for Actual Casual Staff by State, Higher Education Provider and Function in an Academic Organisational Unit, 2007.

Edwards, D. (2010). The future of the research workforce - estimating demand for PhDs in Australia. Journal of Higher Education Policy and Management, 32(2), 199-210.

Edwards, D., and Smith, T. F. (2008). Literature Review and Data Analysis, Supply, Demand and Approaches to Employment by People with Postgraduate Research Qualifications in Science and Mathematics. Canberra: Department of Education, Employment and Workplace Relations, Commonwealth of Australia.

Edwards, D., and Smith, T. F. (2010). Supply issues for science academics in Australia: now and in the future. Higher Education, 60(1), 19-32.

Edwards, D., Bexley, E., and Richardson, S. (2010). Regenerating the Academic Workforce: The careers, intentions and motivations of higher degree research students in Australia. Canberra: Department of Education, Employment and Workplace Relations, Commonwealth of Australia.

Edwards, D., Radloff, A., and Coates, H. (2009). Supply, Demand and Characteristics of the Higher Degree by Research Population in Australia. Canberra: Department of Innovation, Industry, Science and Research, Commonwealth of Australia.

Group of Eight (2010). Future demand for Higher Education in Australia, Group of Eight, Go8 Backgrounder 10. Group of Eight, June 2010.

Hughes, B., and Rubenstien, H. (2006). Mathematics and Statistics: Critical Skills for Australia's Future: the National Strategic Review of Mathematical Sciences Research in Australia (No. 0858472341). Canberra: Australian Academy of Science.

Hugo, G. (2005a). The Demography of Australia's Academic Workforce: The ATN Universities. Paper presented to Australian Technology Network of Universities (ATN) Conference on Building Partnerships: Finding Solutions - The ATN Workforce in Profile, Rydges Hotel, Melbourne: 9-11 February 2005.

Hugo, G. (2005b). Academia's own demographic time-bomb. Australian Universities Review, 48(1), 16-23.

Hugo, G. (2005c). Some emerging demographic issues on Australia's teaching academic workforce. Higher Education Policy, 18(3), 207-230. 
Hugo, G. (2008). The demographic outlook for Australian universities' academic staff. CHASS occasional paper no. 6. Adelaide: Council for Humanities, Arts and Social Sciences.

Hugo, G., and Morriss, A. (2010). Investigating the Ageing Academic Workforce: Stocktake. Adelaide: National Centre for Social Applications of Geographic Information Systems, University of Adelaide.

Huisman, J., de Weert, E., and Bartelse, J. (2002). Academic Careers from a European Perspective. Journal of Higher Education, 73(1), 141-160.

Junor, A. (2004). Casual university work: choice risk and equity and the case for regulation. The Economics and Labour Review, 14(2), 276-304.

May, R., (2011, forthcoming). Casualisation here to stay? The modern university and its divided workforce. In Markey, R. (Ed.), Dialogue Downunder, Refereed Proceedings of the 25th Conference of AIRAANZ. Auckland: AIRAANZ.

McInnis, C. (1999). The Work Roles of Academics in Australian Universities. Canberra: AGPS.

Newcomb, R.G., and Altman, D.G. (2000). Proportions and their differences. In D. G. Altman and R. G. Newcomb (Eds.), Statistics with Confidence (2nd ed). London: BMJ Books.

OECD (2008). The academic career: Adapting to change. In Tertiary Education for the Knowledge Society: Volume 2: Special features: Equity, Innovation, Labour Market, Internationalisation. Paris: OECD.

Parliament of the Commonwealth of Australia (2008). Building Australia's Research Capacity. House of Representatives Standing Committee on Industry, Science and Innovation. Canberra: Commonwealth of Australia.

Skills Australia (2010). Australian Workforce Futures: A National Workforce Development Strategy. Canberra: Commonwealth of Australia.

Universities Australia (2006). 2006 Student to Teacher Ratio For Academic Staff with Teaching Function. http://www.universitiesaustralia.edu.au/documents/publications/stats/SSR2006-stats.pdf. Accessed 10 July 2010.

Winefield, A. H., Boyd, C., Saebel, J. and Pignata, S. (2008). Job stress in university staff: An Australian research study. Bowen Hills: Australian Academic Press.

Winefield, A. H., Gillespie, N., Stough, C., Dua, J., Hapuarachchi, J., and Boyd, C. (2003). Occupational Stress in Australian University Staff: Results From a National Survey. International Journal of Stress Management, 10(5), 51-63. 


\section{University Library}

\section{- M M I E E R VA A gateway to Melbourne's research publications}

Minerva Access is the Institutional Repository of The University of Melbourne

Author/s:

Bexley, E;Arkoudis, S;James, R

Title:

The motivations, values and future plans of Australian academics

Date:

2013-03-01

Citation:

Bexley, E., Arkoudis, S. \& James, R. (2013). The motivations, values and future plans of Australian academics. HIGHER EDUCATION, 65 (3), pp.385-400. https://doi.org/10.1007/ s10734-012-9550-3.

Persistent Link:

http://hdl.handle.net/11343/282612 